\title{
Optimizing Digital Marketing for Generation Y: An Investigation of Developing Online Market in Bangladesh
}

\author{
Syed Mahmudur Rahman ${ }^{1}$ \\ ${ }^{1}$ BRAC Business School, BRAC University, Dhaka, Bangladesh \\ Correspondence: Syed Mahmudur Rahman, BRAC Business School, BRAC University, Dhaka, Bangladesh. Tel: \\ 88-01-777-764-791. E-mail: syed.ma.rahman@gmail.com
}

Received: July 1, 2015

doi:10.5539/ibr.v8n8p150
Accepted: July 21, 2015

Online Published: July 25, 2015

URL: http://dx.doi.org/10.5539/ibr.v8n8p150

\begin{abstract}
This market research aims to investigate the digital information scanning and the internet using habit of Generation Y in Bangladesh, a rapidly developing e-commerce market. It also examines the key variables to optimize digital advertisement for the target group. The study segments Gen Y into two age groups, 18-25 who are students and between 26-35 years who are working, in order to explore the transformation in online consumer behaviour. Most data have been presented according to the segments and gender. The analysis in this study is based on 305 face to face surveys during April-June 2015 using structured questionnaires. This research found that Gen Y with internet access living in the capital of Bangladesh has similar traits as found in many researches focused on developed online market. Facebook is their primary source of information and they have moved away from watching TV. But they are still exposed to the traditional advertisements through billboards and other non-digital media. They are mostly active online on Facebook, Google and YouTube from 5PM to 2AM. This information, along with other findings in this research, provides rich data for advanced targeting variable in Google AdWords and Facebook Advertising. Pop-up ad is the least liked feature by Gen Y. They prefer innovative and interactive ads displaying new product information. They also tend to click on online ads showing discount coupons and similar offers. Ads representing social benefits motivate Gen Y. This study sets a benchmark as it is the first of its kind in the context of Bangladesh. Thus it can be used as the foundation of a longitudinal study on the topic.
\end{abstract}

Keywords: E-commerce, marketing strategy, online consumer behaviour, generation Y, online marketing, digital marketing, internet marketing

\section{Introduction}

E-commerce in Bangladesh is observing rapid growth and medium to large size organizations have started to invest in online marketing. Latest Internet World Stats (2015) of Bangladesh presents that $26.4 \%$ of the population already have access to internet as of 14 June 2015 and Facebook.com tops the list of most accessed online service (Alexa, 2015). Bangladesh has a young population and the recent study by Rahman (2015) examined the expectations of Generation Y (Gen Y) from online retailers in Bangladesh. The findings of that research provide a direction to the market to invest in online retail ventures which are in demand by the target group i.e. Gen Y. As more consumers are going online, the marketing strategists should feel the importance of reaching the target group in the most efficient way. As a result the need for digital advertisement is growing in parallel with the growth of e-commerce. Studies to assist such market transformation is available for developed market (Chan-Olmsted, Rim, \& Zerba, 2013; Lewis, 2008) but there is a gap in market research to investigate the consumer behaviour in developing market such as Bangladesh. An investigation of current online information scanning habit of Gen $\mathrm{Y}$ is required to understand their digital activities. The outcome can set a benchmark for the digital marketers in Bangladesh and a longitudinal study (Note 1) similar to the work of Taken Smith (2012) can be the next step to observe the transformation in online consumer behaviour.

The purpose of this study is to investigate how different segments of Gen Y in Bangladesh utilize the source of digital information. The objectives of this study are to:

1) Investigate the digital information scanning habit of Gen $Y$.

2) Investigate the internet using habit of Gen Y. 
3) Investigate key variables to optimize digital advertisement targeting Gen $Y$.

This article starts with a brief literature review on Gen Y consumer behaviour. The methodology section explains the process of developing questionnaire and data collection. The findings of the survey are presented in the following section. Lastly a detailed examination of the results followed by practical implications and further research recommendations is provided.

\section{Literature Review}

Gen Y consumer behaviour is an extensively researched area. Black (2010) investigated the learning habit of group of US college students to prepare the faculties better so that they can meet the demand of the generation. Gen Y's dependence on technology was highlighted as the most important outcome of that research and the author characterised Gen Y as 'Digital Natives'. This term was first used by Marc Prensky (2001) to recommend a radical change in US education delivery system. The term native represents the native language that we speak, the way we think and the cultural armour that we inherit. Gen Y inherited a world triumphing digital technology. They have seen the birth and aided the rapid growth of applications and devices such as Facebook, iPhone and Cloud computing which reshaped the way we do our work today. Comparing Bangladesh with US or Australia, a rapidly developing digital market vs. a highly developed region, the example is in front of us and the need for understanding the ways to deliver information to Gen Y in Bangladesh is immense.

Understanding the information delivery channel is not only important for socio-cultural and globalization reasons but also for the commercial purpose. Internet penetration from mobile devices is increasing in Bangladesh and the lowering internet bandwidth and device cost is the key reason driving the change (Rahman, 2015; Taher, 2015). Also recent affiliation between local telecommunication organization Grameenphone (GP) and the world's largest NGO BRAC to provide smart mobile handset with internet access for a year may have a strong impact on the digital media access from rural areas in Bangladesh (Grameenphone, 2015a, 2015b). Closing the gap of internet availability between the urban and rural demographics of Bangladesh will complement the already praiseworthy digital growth in the country over the past five years. Digital access to more consumer base will create opportunities to increase advertisement reach rapidly. Digital media attracts consumer due to its interactive nature which also help the brands to visualize consumer preferences. Flow of such data should help brands to co-create products and services which is one of the key value that attracts Gen-Y (De Vries \& Carlson, 2014; Rahman, 2015).

In 2014, neighbouring country India, with similar demographics and growing e-commerce market as Bangladesh, spent $\$ 740$ million on digital ad out of $\$ 6.1$ billion in total advertisement expenditure (eMarketer, 2015). There are two primary mediums of online advertisements; first is the search engine and second is the social media. Social media such as Facebook is not only a mass social communication media but also one of the largest digital marketing platforms. In developed US market, on an average, an adult uses 6\% (21 minutes) of their daily time on Facebook (eMarketer, 2014); viewing advertisements (sponsored post) and posts by preferred brand's Facebook pages (BFP post feed) are part of this mix. In that mix of adult users, 26.2 million $(16.7 \%)$ are in the age group of 18-24 and 32.1 million (20.5\%) are in 25-35, which comprises Gen Y population segment (AdWeek, 2015). It is evident from the data that Gen Y is exposed to advertisement delivered through Facebook i.e. social media in developed e-market and presumably similar trend will be observed in Bangladesh as the access to digital media grows. Interestingly social media advertisement is relatively new considering Google's online advertising platform 'AdWords' was launched in 2000 (Google, 2014). Google has enjoyed a 19\% year-over-year profit rise in year 2013-2014 and much of it is contributed by the increased paid advertisement (21\% rise in AdWords revenue) (Dent, 2014). Growth of e-commerce in developing market as well as increased advertisement in developed market is helping Google to grow. From the advertisers' perspective, knowing the best way of AdWord's ROI (Note 2) is the key concern (Dent, 2014; Stelzner, 2015), which includes knowing the internet behaviour of the target consumer group.

The preference of digital advertisement varies between different demographics. A New York based research in 2010 found that leader boards, blogs, videos and brand pages are preferred by the respondents, and Pop-ups, expandable and floating ads have perceived negative attributes (Cox, 2010). The study also found that the age group of 18-28 (Gen Y at the time of this research) is not too concerned about the placement of the ad on a site but the same attribute is important to 35-54 age groups. Another earlier US study found that average people use four different media such as online news portal, Word of Mouth (WoM (Note 3)), Television, Facebook, Twitter, YouTube, LinkedIn to receive news (Lewis, 2008). The findings of that research highlighted the falling of online news reader in the age group of 18-29 as alarming. The alarm was raised mainly because the young group of online population was moving away from the news portals to the websites and services which are not primarily 
news oriented. The researcher described the situation as 'Odd' and recommended regular evaluation of the internet habit of Gen Y.

Theory of Uses and Gratification is widely used in social media research and to identify the motivational factors to reach and influence Gen Y digitally (De Vries \& Carlson, 2014; Lewis, 2008; Lichy, 2012). As researchers found that Gen $\mathrm{Y}$ is moving away from the mainstream media to much newer and interactive media, most of the time they are entering those media with perceived functional and hedonic value. Evaluating some of those values to attract Gen Y, researchers recommended to make digital content interesting and to set strategies to deliver content at the right moment to the right target to fulfill the functional value that they are seeking from digital media (Sharma, 2011). Sharma (2011) also highlighted the wrongdoings of the management by distributing digital content anytime. For example, Facebook wall is updated frequently to present latest information, Twitter is designed to have lots of frequent update and people use their smartphones to receive news while they are stuck in traffic during peak hours. Misunderstanding the digital media and misuse of digital advertisement delivery mechanisms can deprive consumers from the value that they seek online. Thus it is important for the brands to understand the digital eco system of their target market.

\section{Methodology}

\subsection{Study Design}

The target group of this research is between the age of 20 and 35 years. Not everyone within Gen $\mathrm{Y}$ has the same earning and also their need for digital media access is different. Thus it is obvious to expect differences between different age segments depending on the highest level of education, gender, work status and lifestyle (Bakewell \& Mitchell, 2003; Noble, Haytko, \& Phillips, 2009). Young university students and graduates within the age limit of 20 to 25 years are part of Gen Y and they have been segmented as students with no or limited income source. The second segment of the target group is in between the age of 26 to 35 years who are employed or unemployed after completing their graduation from the university. This age group is regularly utilized by researchers and corporations to develop product in a consumer controlled market (Chu \& Choi, 2011; Mangold \& Faulds, 2009). Self-administered paper-and-pencil intercept survey deemed appropriate for the purpose of this research as the target group is young adults (De Vries \& Carlson, 2014). Similar to recent Gen Y study by Rahman (2015), final year students at BRAC University volunteered for the survey. Initial screening found their birth year is between 1991 and 1994. This age cluster of 21-24 years (middle aged Gen-Y) are students with no or part-time jobs. The same group of volunteers assisted to collect self-administrated survey from their elder family members and friends born between 1980 and 1995. They are 25 to 35 years old and most of them are working full time or engaged in business activities. All volunteers have good English reading and writing skill to administer a survey.

This research aims to map the digital information scanning habit of the target group; thus most questions were prepared to be suitable for statistical analysis using SPSS version 17. The survey questionnaire had 43 questions to capture the behavioural data of respondents' search engine use, exposure level to digital advertisement, understanding of online advertisement, television watching habit and most of all-the time of the day and night when they are active online. Current concerns of digital marketers such as 'how to find target audience', 'how to deliver advertisement more efficiently' (Stelzner, 2015), 'effectiveness of online advertisements' (Criteo, 2015) were in mind while preparing the questions. There were four open ended questions to learn about their reason of why they have stopped visiting a website that they used to visit, their general dislikes of frequently accessed websites and their preferred online advertisement methods. Few questions were prepared following Likert scale to understand respondent's attitude. Most of such questions had five response options (Never-Always) and few had three response options (not at all, occasionally and frequently). All volunteers received adequate information on each topic so that any question from the participant can be answered. The survey also included questions about their general view on online shopping in Bangladesh. Preparation for this research started in late- 2014 and data collection was conducted in the months of May and June, 2015.

\subsection{Sample Profile}

In total, 317 completed surveys were collected and 305 were usable for data entry after initial screening. Of this sample, 164 are in the age group of 20-25 with 89 male and 75 female. 137 of them are currently studying at private universities, 16 of them works part time while continuing their study at the university and 7 working full-time after completing graduation recently. 141 respondents are from the age group of 26-35 with 88 males and 53 females. Only 12 of them are still at the final year of their graduation at the university, 101 respondents are working full-time and 22 are unemployed. In total, $49.2 \%$ student, $35.4 \%$ full-time employee, $7.5 \%$ unemployed, $5.6 \%$ student with part-time work and $1.3 \%$ full-time work with part-time study. Out of 305 
respondents, 2 respondents completed their $\mathrm{PhD}, 27.2 \%$ completed master's degree, $23.3 \%$ completed their bachelor degree, $46.6 \%$ are final year university student and $2.3 \%$ completed up to HSC level. The overall male and female ratio in the data is 164:141 which should represent an unbiased analysis.

\section{Results and Discussions}

\subsection{Usage of News Media by Gen Y}

Digital and non-digital media have been considered to identify the channels that Gen Y uses to receive news. Internet and telecast have been considered as digital channel. Face to face conversations and printed newspaper have been considered as non-digital media. Respondents $(N=305)$ were asked one question to select their primary source of information and frequency analysis in table 1 shows difference based on age group. The observation in table 1 shows that Gen Y uses Social Media platform Facebook as the primary source of news. Stronger tendency in seen in the 18-25 age groups than 26-35. Female in all age groups use Facebook more as a news source than men, which supports the findings of a recent Malaysian study with similar setup (Zaremohzzabieh, Samah, Omar, Bolong, \& Kamarudin, 2014).

Table 1. Gen Y news channels

\begin{tabular}{lcccc}
\hline \multirow{2}{*}{ Information channel } & \multicolumn{2}{c}{ Age group 18-25 } & \multicolumn{2}{c}{ Age group 26-35 } \\
\cline { 2 - 5 } & Male (\%) & Female (\%) & Male (\%) & Female (\%) \\
\hline Total $N=305$ & $N=89$ & $N=75$ & $N=88$ & $N=53$ \\
\hline Printed new paper (Offline) & 11.3 & 3.1 & 11.3 & 7.8 \\
Television & 1.7 & 7.0 & 6.8 & 7.8 \\
Facebook (Social Media) & 20.9 & 11.3 & 14.1 \\
Chat with friends (WoM) & 1.7 & 10.9 & 1.1 & 0.8 \\
Online news portals & 13.6 & & 18.1 & 9.4 \\
\hline
\end{tabular}

Having chat with friends is the least used media to receive information across all age groups and gender. This is not surprising as Gen Y is meeting more friends online than offline; they are virtually connected. Online news portals still attract reasonable percentages of Gen Y for their daily news feed. Conversation with the respondents revealed that the feed from the news portals on their Facebook wall is the way to connect to those online services. Having feed in the Facebook saves them from going to an external site. Many telco provides free access to Facebook from mobile connections, thus Facebook is their only option to receive updated news while on mobile without Wi-Fi internet connection. Offline printed newspaper is still preferred by almost the same amount of respondents who receive information from online news portals with the exception of female in 18-25 age group. Facebook is the most preferred news channel (35\%) to that segment by far compared to $3 \%$ who reads printed newspaper.

Differences in TV viewing habit is noticeable as only $1.7 \%$ male in the $18-25$ age group watch TV and consider it as a news source. Four more questions were asked to the respondents to better understand their TV watching habit. The analysis shows that most respondents occasionally watch TV but local Bangladeshi channels are not popular among any target segment. Table 2 shows that most male prefers to watch foreign English channels, most female prefers Indian Hindi channels and Bangladeshi channels are watched by merely $15 \%$ respondent.

Table 2. TV watching habit

\begin{tabular}{lcccc}
\hline & Do not watch TV & Foreign English Channel & Indian Hindi & Bangladeshi Channel \\
\cline { 2 - 5 } Total $N=305$ & $N=35$ & $N=162$ & $N=60$ & $N=48$ \\
\hline Male & $7.2 \%$ & $35.1 \%$ & $3.9 \%$ & $11.8 \%$ \\
Female & $4.3 \%$ & $4.3 \%$ & $15.6 \%$ & $3.9 \%$ \\
\hline
\end{tabular}

305 respondents also informed their preferred time to watch TV and there is no significant difference between the age groups, gender and types of days i.e. weekday vs. weekends. Most people watch TV in between 10PM to 
$2 \mathrm{AM}$ (weekday, weekend $=48 \%, 39 \%$ ). The second peak period is from 5PM to 10PM (weekday, weekend $=$ $38 \%, 38 \%$ ). Off-peak period is $2 \mathrm{AM}$ to $8 \mathrm{AM}$ (weekday, weekend $=2.6 \%, 4.3 \%$ ). The interviewers asked predesigned open ended question to learn more about TV habit. It was found that most respondents with good internet connection at home do not feel the need for exclusive TV watching time. They still prefer to watch videos but they preferred watching YouTube videos in their own domain rather than sharing one TV with other family members and avoid everyone watching the same channels at the same time. Possibly the value of 'self' is dictating their means to fulfil hedonic value.

But a person is exposed to multiple media sources, thus four more questions were asked in Likert scale (never, rarely, sometimes, most of the time, always) to understand the relation between their news seeking habit, gender and age. Following hypotheses were formed to statistically test such relationships:

$H_{l a}=$ Likelihood to read printed newspaper do not vary between gender

$H_{l b}=$ Likelihood to read printed newspaper do not vary between Gen Y age group

$H_{2 a}=$ Likelihood to visit online news portals do not vary between gender

$H_{2 b}=$ Likelihood to visit online news portals do not vary between Gen $\mathrm{Y}$ age group

$H_{3 a}=$ Likelihood to watch TV do not vary between gender

$H_{3 b}=$ Likelihood to watch TV do not vary between Gen Y age group

$H_{4 a}=$ Likelihood to observe billboards do not vary between gender

$H_{4 b}=$ Likelihood to observe billboards do not vary between Gen Y age group

Chi-square test of independence using SPSS was used to test association between variables in each of these hypotheses. At $\mathrm{t}_{305}, \mathrm{P}$-value of $0.488\left(\mathrm{x}_{5}{ }_{5}=4.441, \mathrm{p}>0.05\right)$ fails to reject $H_{l a}$, indicating no relation between gender and printed newspaper reading preference. But P-value of $0.031\left(\mathrm{x}^{2}{ }_{4}=10.632, \mathrm{p}<0.05\right)$ for $H_{2 a}$ test reflects strong relationship (Cramer's V value of 0.187 which is $>0.15$ ) between gender and online newspaper reading habit. Similarly, test for $H_{3 a}$ found strong relationship (Cramer's V value of 0.266 which is $>0.25$ for $\mathrm{P}$-value of 0.000 with $\mathrm{x}_{3}{ }_{3}=21.604$ at $\mathrm{t}_{305}$ ) between gender and TV viewing habit. Analysis of the data table reveals that most of the male (37\%) watch TV occasionally and $16 \%$ watch TV frequently. In terms of female, $23 \%$ watch frequently and $17 \%$ watch occasionally. Comparing with findings in table 2 , it can be assumed that most male are frequently watching foreign English movies whereas most female are watching Indian Hindi channels. In terms of looking at billboards besides roads and highways $\left(H_{4 a}\right)$, there is a strong relationship among gender, specially female, and their habit of receiving information from ads $\left(\mathrm{x}^{2}{ }_{5}=15.649, \mathrm{P}\right.$-value $=0.008$ and Cramer's V=0.227). Similar to gender, Chi-square test was used to examine relation between age group and their news receiving process. Following are the test results for four hypotheses at $\mathrm{t}_{305}$ :

$H_{l b}=\mathrm{P}$-value of $0.089\left(\mathrm{x}^{2}=9.537, \mathrm{p}>0.05\right)$; Cramer's V value of 0.177

$H_{2 b}=\mathrm{P}$-value of $0.463\left(\mathrm{x}^{2}{ }_{4}=3.598, \mathrm{p}>0.05\right)$; Cramer's $\mathrm{V}$ value of 0.109

$H_{3 b}=\mathrm{P}$-value of $0.524\left(\mathrm{x}_{5}{ }_{5}=2.240, \mathrm{p}>0.05\right)$; Cramer's $\mathrm{V}$ value of 0.086

$H_{4 b}=\mathrm{P}$-value of $0.170\left(\mathrm{x}_{5}{ }_{5}=7.759, \mathrm{p}>0.05\right)$; Cramer's $\mathrm{V}$ value of 0.159

All four tests fail to reject the null hypothesis signifying that Gen Y's habit of receiving news from printed newspaper, online newspaper, TV and billboards does not change significantly as they grow older. In summary of these tests, possibly, billboards are effective media for offline advertisements to female; online newspapers are effective for advertisements targeting male. It can also be concluded that advertising on local Bangladeshi TV channels may not be effective if the product is targeted to the demography similar to the respondents in this study. But running video advertisements i.e. TV Commercial (TVC) in YouTube and Facebook at specific times of the day can provide better reach. Some related analysis is available in following sections.

Some outcomes in this analysis indicate that information receiving habit of Gen Y in Bangladesh is not so different from the global trend. Recent research by American Press Institute (2015) found that 18-34 years old US population do not read print media and do not watch TV for news. They spend more time in social media and accept the news that are fed to their apps in mobile devices. These findings do not mean that Gen Y is less exposed to news. On the contrary, they now more open to news channels as they have more options available to them. They customize those channels as per their own liking to create their own news feed. The research also found that news related to social cause attracts Gen Y. This view supports 'Share used mobile device' strategy by BRAC and GP described earlier in the literature review section. A UK based study found that charities are finding it challenging to attract Gen Y using traditional advertising and fund seeking method (Meade, 2014). 
Following the findings of this research in Bangladesh and earlier researches on Gen Y, GP should be able to gain the attention of Gen Y by supporting a social cause and BRAC should be able to reach its next generation of donor by partnering with a telco which has higher access to Gen $\mathrm{Y}$ due to their high telecom products and services usage habit.

\subsection{Internet Using Habit of Gen Y in Bangladesh}

The amount of time spent on internet, the types of devices used to surf internet and the peak internet usage time are important information to customize digital advertisement delivery to different age and gender groups. Multiple questions were asked during the survey to map the Internet usage habit of Gen Y. Table 3 shows the amount of time that respondents spend on Internet daily:

Table 3. Gen Y Internet usage in hours

\begin{tabular}{|c|c|c|c|c|}
\hline \multirow{2}{*}{ Hours spent on Internet } & \multicolumn{2}{|c|}{ Age group 18-25 } & \multicolumn{2}{|c|}{ Age group 26-35 } \\
\hline & Male (\%) & Female $(\%)$ & Male $(\%)$ & Female $(\%)$ \\
\hline Total $N=305$ & $N=89$ & $N=75$ & $N=88$ & $N=53$ \\
\hline 1-2 hours (low usage) & 8.5 & 11.7 & 12.4 & 15.6 \\
\hline $2-5$ hours (medium usage) & 23.7 & 23.4 & 15.8 & 14.1 \\
\hline 5 hours+ (high usage) & 18.1 & 22.7 & 21.5 & 11.7 \\
\hline
\end{tabular}

It is not surprising to find that most respondents in the 18-25 age groups are spending at least 2-5 hours on the internet. Chi-square test of $H_{5 a}$, association between gender and internet usage, finds no association between the variables at $\mathrm{t}_{305}$ with $\mathrm{P}$-value of $0.348\left(\mathrm{x}_{3}^{2}=9.537, \mathrm{p}>0.05\right)$. But $H_{5 b}$, relation between Gen $\mathrm{Y}$ age group and internet usage, indicates Strong relationship at $\mathrm{t}_{305}$ with $\mathrm{P}$-value of $0.05\left(\mathrm{x}_{3}{ }_{3}=7.599, \mathrm{p}>0.05\right)$ and Cramer's $\mathrm{V}$ value of $0.158(>0.15)$. It is evident from table 3 that the percentage of low, medium and high usage is almost evenly spread in the age group of 26-35 years, with the exception of that more male (21.5\%) are heavy internet users than female $(11.7 \%)$. The increase in the low usage group is possibly due to the fact that respondents in this group are working full-time or part-time. This finding supports the earlier finding in table 1 that very few female $(9.4 \%)$ in the age group of 26-35 are reading online newspaper. But their Facebook usage remains reasonably high, meaning this group of female utilizes their internet time mostly on Facebook i.e. Social Media. Heavy usage of internet by working male resonates the US finding where approximately $73 \%$ of the employee from the 18-35 age group spend time in non-work related internet browsing (Conner, 2012). The Gen Y employees in that survey mentioned boredom at work as their reason for being inefficient.

Table 4. Primary device for internet access

\begin{tabular}{lccccc}
\hline & Mobile Phone & Laptop & Desktop & Tablet & Both laptop and Mobile \\
\hline Total $N=305$ & $N=96$ & $N=115$ & $N=48$ & $N=12$ & $N=34$ \\
\hline Male & $16.1 \%$ & $23.9 \%$ & $11.5 \%$ & $1.0 \%$ & $5.2 \%$ \\
Female & $15.4 \%$ & $13.8 \%$ & $4.3 \%$ & $2.6 \%$ & $5.9 \%$ \\
Total: & $31.5 \%$ & $37.7 \%$ & $15.7 \%$ & $3.6 \%$ & $11.1 \%$ \\
\hline
\end{tabular}

The study did not observe any significant difference in the types of devices that respondents from different age groups primarily use for internet access. But there are some differences between genders. Table 4 shows that laptops $(37.7 \%)$ are the primary device for internet access by most of the respondents followed by mobile phones $(31.5 \%)$. Desktops are preferred by more male than female. Conversation with the male respondents revealed that they use high end desktops to play video games. Tablet is yet to become popular but more female are using tablet than male. Some female respondents started to use tablets due to its lightweight feature. Most respondents prefer mobile phones with larger screen size than tablet because it is easier to enable internet access in mobile phones whereas tablets can access internet with Wi-Fi connection only. One male respondent of final year business degree made a fun out of Maslow's hierarchy of need and wanted to add mobile phone and internet in the list. Perhaps providing free Wi-Fi connection can be a viable strategic decision by businesses if they need to 
lure Gen Y in their premises.

Respondent's answers to the question of their purpose of internet usage revels that they mostly use internet for following reasons: Facebook i.e. social media-37\%, searching on Google-32.5\%, academic research-16\%, watching video online- $7 \%$, reading news $-3.9 \%$, play video games- $-1.3 \%$, official use $1 \%$ and online shopping $1 \%$. While shopping or evaluating products online consumers most of the traffic in developed online market (PWC, 2015a, 2015b), Bangladesh is not experiencing that traffic load yet. Table 5 maps the peak and off-peak internet usage time of Gen Y where weekends are Fridays and Saturdays. Not surprisingly most respondents are always online and surfing internet as they require. Respondents in the age group of 18-26 years are not highly active on the internet during standing working hours of $9 \mathrm{am}$ to $5 \mathrm{pm}$ but they are highly active from $5 \mathrm{pm}$ onwards and mostly active late in the night (18.4\%). Respondents from the age group of 26-36 years are moderately active on the internet $(8.9 \%)$ despite their work commitment during $9 \mathrm{am}$ to $5 \mathrm{pm}$ on the weekdays. Both Google AdWords and Facebook advertisement platform offers targeting option based on time. This time map can be utilized to optimize online advertisement targeting Gen Y in Bangladesh.

Table 5. Gen Y internet browsing time

\begin{tabular}{lcccc}
\hline \multirow{2}{*}{ Information channel } & \multicolumn{2}{c}{ Age group 18-25 } & \multicolumn{2}{c}{ Age group 26-35 } \\
\cline { 2 - 5 } & Weekdays $(\%)$ & Weekends $(\%)$ & Weekdays $(\%)$ & Weekends $(\%)$ \\
\hline Total $N=305$ & $N=164$ & $N=164$ & $N=141$ & $N=141$ \\
\hline Always online & 20.0 & 27.9 & 22 & 24.6 \\
$8 \mathrm{am}-5 \mathrm{pm}$ & 3.3 & 4.3 & 8.9 & 6.3 \\
$5 \mathrm{pm}-10 \mathrm{pm}$ & 11.8 & 7.5 & 7.5 & 11.1 \\
$10 \mathrm{pm}-2 \mathrm{am}$ & 18.4 & 12.1 & 0.7 & 6.2 \\
$2 \mathrm{am}-8 \mathrm{am}$ & 0.3 & 1.3 & & 1.3 \\
\hline
\end{tabular}

\subsection{Advertising to Gen Y in Bangladesh}

Taken Smith (2012) conducted a longitudinal study in US from 2009 to 2011 and found that Gen Y is more attracted to advertisement with discount coupons and overwhelmingly hate pop-up ads. It is important to investigate the preference of Gen $\mathrm{Y}$ in Bangladesh to deliver advertisements that they prefer. For example, http://www.prothom-alo.com is the highest ranked online news portal in Bangladesh (Alexa, 2015) and often it displays pop-up ads on the homepage. Many respondents in this research directly mentioned their frustration with the pop-up ads on their preferred news media; digital ad channels should pay more attention to the preference of their audience. Few questions were asked in this research to understand their advertisement preference. 34\% respondents $(\mathrm{N}=305)$ from all segments answered that they 'Sometimes' look at the billboards besides the streets and highways and another 34\% said that they notice billboards 'Most of the times'. About 20\% population always notice billboards while they are travelling on the road. This result indicates that offline advertisement media such as billboards and banners are still appealing to Gen $\mathrm{Y}$ in Bangladesh. There is no significant difference between the billboard viewing preference of male and female.

Table 6. Understanding of digital marketing techniques

\begin{tabular}{lcccc}
\hline & $\begin{array}{c}\text { Can differ between paid and } \\
\text { unpaid search result on } \\
\text { Google/Bing }\end{array}$ & $\begin{array}{c}\text { Can Differ paid and } \\
\text { unpaid post or ad on } \\
\text { Facebook }\end{array}$ & $\begin{array}{c}\text { Receive SMS } \\
\text { advertisement }\end{array}$ & $\begin{array}{c}\text { Developed a skill to skip online } \\
\text { advertisement and view desired content } \\
\text { only }\end{array}$ \\
\hline N=301 & $N=301$ & $N=301$ & N=302 \\
\% Yes & $\%$ Yes & 38.9 & Yes \\
\hline Female & 29.5 & 37.6 & 27.6 & 33.8 \\
Total: & 16.1 & 23.4 & 66.4 & 54.6 \\
\hline
\end{tabular}


Table 6 and 7 shows answers to few digital advertisement related questions. These questions were asked to find out the current level of awareness and psychological acceptance of digital advertisement. Recent researches on online advertisement found that the audience have developed a skipping behaviour because the advertisements are always on the same spot on a delivery channel i.e. website, mobile app (Nettelhorst, Jeter, \& Brannon, 2014). Table 6 shows that almost 55\% respondents have already developed skill to take what they need from a media and avoid looking at unwanted content which do not interest them. SMS advertisement seems popular with the marketers as more than $65 \%$ respondents are receiving offers via SMS. $61 \%$ respondents can differentiate between organic and paid news feed on Facebook and 45\% knows which search results are sponsored by the company itself rather than recommended by Google. These findings indicate relationship between someone's ability to differentiate between paid/unpaid online advertisement and their habit of overlooking ads on websites. Thus a paired t-test was conducted using SPSS for the hypothesis:

$H_{6}=$ Mean score of ability to differentiate online ad type and habit of overlooking online ads are the same. The mean difference is zero: $\mu_{\mathrm{d}}=0$.

Paired Samples test outcome from SPSS provided $\mathrm{p}=0.097$, which is more than 5\% significance level of 0.05 at $\mathrm{t}_{301}$. The means for two variables are similar as well $\left(\mu_{\mathrm{d}}=0\right)$. Thus statistically there is no significant difference in someone's ability to differentiate between paid/unpaid ads and their habit to skip online ads. Therefore the test fails to reject $H_{6}$. The output also shows a positive correlation of 0.113 . These findings support the online advertisement skipping habit as found in other researches in developed e-commerce market as explained earlier. Innovative marketing and web design strategies implemented in such markets to engage consumers in online ads can be followed by managers in developing Bangladesh market to keep reaching online consumers despite Gen Y's negative attitude towards ads on websites.

Analysis of 4 more questions shown in table 7 indicates that advertisements via mobile apps have the lowest chance of success (about $83 \%$ deny rate) but other digital advertisements are still clicked by $25-35 \%$ Gen Y. Chi-square test of independence shows no significance relation ( $p>0.05$ at $\left.t_{305}\right)$ among the preferences in table 7 , respondent's age group and their gender. This acceptance level asks two questions-'What type of advertisements does Gen Y prefer?' and 'What type of advertisements do Gen Y hate'; table 8 provides their answer. Their answer supports the US study mentioned earlier that pop-ups are mostly hated by all Gen Y. Also they are not attracted to an ad if it is not designed attractively. They also feel betrayed if the advertisement provides wrong information to have their attention. They lose trust on the brand as well as the ad delivery channel in such cases. Businesses can show their new products and information to increase brand knowledge in their attempt to attract Gen Y through digital advertisement. These expectations match the US study which found graphics, personalization, bright colour and interactivity as the preferred web features (Taken Smith, 2012). Similar to developed e-commerce market, Gen Y in Bangladesh is influenced by coupons and other types of incentives delivered through digital advertisement channels. These variables lead to the final question of - 'What is the best way to advertise a product or service to you'. There was no significant difference between the age and gender groups; table 9 lists the top eight answers:

Table 7. Negative acceptance rate of digital advertisement

\begin{tabular}{lccccc}
\hline & $\begin{array}{c}\text { Does not click on ads } \\
\text { on Website }\end{array}$ & $\begin{array}{c}\text { Does not watch video ad } \\
\text { before YouTube video }\end{array}$ & $\begin{array}{c}\text { Does not click on } \\
\text { ads shown on apps }\end{array}$ & $\begin{array}{c}\text { Does not read } \\
\text { SMS } \\
\text { advertisement }\end{array}$ & $\begin{array}{c}\text { Does not open or } \\
\text { click Email } \\
\text { advertisement }\end{array}$ \\
\hline \% Not at all & N=306 & Not at all & \% Not at all & \% Not at all & \% Not at all \\
\hline Male & 42.3 & 34.8 & 48.3 & 33.1 & 42.3 \\
Female & 27.9 & 26.9 & 33.8 & 21.6 & 33.1 \\
Total: & 70.2 & 61.6 & 82.6 & 54.8 & 75.4 \\
\hline
\end{tabular}


Table 8. Top advertisement preference of Gen Y

\begin{tabular}{lclc}
\hline \multicolumn{2}{c}{ Things Gen Y hate on ad } & \multicolumn{2}{c}{ Things Gen Y want on ad } \\
\hline \multicolumn{1}{c}{ Item } & Percentage $(N=298)$ & \multicolumn{1}{c}{ Item } & Percentage $(N=262)$ \\
\hline Pop-up ad & $74.2 \%$ & Product variety & $24.8 \%$ \\
Bad design and colour & $13.2 \%$ & Educational / Learning & $11.2 \%$ \\
Wrong information & $10.2 \%$ & Offers / Coupons & $9.4 \%$ \\
Slowness and redirection & $6.2 \%$ & Innovative and interactive & $7.2 \%$ \\
\hline
\end{tabular}

The results in table 9 highlights the importance of traditional offline advertisement i.e. billboard and door to door. Surprisingly ads on printed newspaper are not preferred by Gen Y. The outcome also demands better understanding of Facebook i.e. social media habit of Gen Y. Digital Marketers also need to know the specific websites and the types of websites that Gen $\mathrm{Y}$ is visiting in order to place advertisements efficiently i.e. Ad placement options available in Google AdWords and user demography in Facebook advertising. About 60\% of Gen Y uses internet exclusively to go to Facebook.com, Google.com and YouTube.com. 3.3\% visits Cricinfo.com regularly to follow cricket scores and news. About 3\% visits Torrent websites for downloading movies. Prothom-alo.com is the most popular news portal with $2.6 \%$ regular Gen Y visitors. Other frequently visited websites are Androidauthority.com, Daraz.com, Wiki, 9GAG, BDJobs.com, Shohoz.com, Fashion website, websites with tech information.

Table 9. Advertisement media for Gen Y recommended by Gen Y

\begin{tabular}{lc}
\hline Preferred media & Percentage $(N=305)$ \\
\hline Facebook advertisement & $17.2 \%$ \\
Billboard & $17.1 \%$ \\
Ads on websites & $14.1 \%$ \\
TV commercial & $11.1 \%$ \\
Facebook and billboard & $7.9 \%$ \\
Door to door & $3.6 \%$ \\
Facebook and TV commercial & $3.0 \%$ \\
SMS, YouTube, Phone call & $1.2 \%$ \\
\hline
\end{tabular}

\subsection{Digital Communication Trait of Gen $Y$}

Since social media has become the most prominent platform to reach Gen Y, few questions were asked to have a baseline understanding of their traits. Although WhatsApp, Viber and Skype are not classified as social media, related data have been collected during this research to understand communication media of Gen Y. Not surprisingly Facebook tops the list. Similar to earlier study in the similar setup (Rahman, 2015), WhatsApp, Viber and Skype are found to be heavily used by all age groups and gender, but more by younger ladies and elder men. It seems Pinterest is gaining popularities among younger female group (age 18-25). Twitter is less popular in Bangladesh than Instagram. It appears that younger age group of 18-25 is a bigger user of Instagram. Myspace is almost non-existent among Gen $\mathrm{Y}$ in Bangladesh. This data is important from marketing and managerial perspective. These groups of people are future and existing human assets of different organizations. They are a generation which is willing to communicate via internet media rather than traditional phone call. For organizations it provides cost savings opportunities and for marketers it offers better reach. In this survey, about $60 \%$ respondents uses there mobile phone to access Facebook and 25\% uses laptop. 
Table 10. Social media and communication application usage by Gen Y

\begin{tabular}{lcccc}
\hline \multirow{2}{*}{ Media and application } & \multicolumn{2}{c}{ Age group 18-25 } & \multicolumn{2}{c}{ Age group 26-35 } \\
\cline { 2 - 5 } & Male (\%) & Female (\%) & Male (\%) & Female (\%) \\
\hline Total $N=305$ & $N=89$ & $N=75$ & $N=88$ & $N=53$ \\
\hline Facebook & 99.0 & 99.0 & 100 & 100 \\
Twitter & 16.9 & 13.3 & 11.3 & 3.9 \\
Instagram & 26.6 & 31.3 & 19.2 & 12.5 \\
Pinterest & 6.2 & 14.2 & 2.8 & 1.6 \\
Myspace & 1.7 & 0.0 & 31.6 & 24.6 \\
WhatsApp & 36.2 & 43.0 & 39.0 & 33.6 \\
Viber & 40.7 & 51.6 & 37.3 & 25.8 \\
Skype & 39.5 & 50.0 & & 2 \\
\hline
\end{tabular}

\subsection{Online Purchase Behaviour of Gen $Y$}

Table 11 displays the spread of Gen $\mathrm{Y}$ who has already started online shopping. It is noticeable that younger Gen Y, especially female $(42.5 \%)$ have already purchased online, indicating this consumer segment is valuable to ecommerce sector. Chi-Square test also indicates moderate relation between age group and online shopping habit $\left(0.132\right.$ at $\mathrm{t}_{302}$ with $\mathrm{p}=0.022$ where $\left.\mathrm{p}<0.05\right)$ but does not show any significant relationship between respondent's gender and their online shopping habit $\left(-0.077\right.$ at $\mathrm{t}_{302}$ with $\mathrm{p}=0.179$ where $\left.\mathrm{p}>0.05\right) .30 \%$ of the online purchaser bought cloths and jewellery, about 15\% bought sports, toys, footwear, gift items and electrical items, 3\% bought books. This figures supports the earlier findings that Gen Y wants more cloths and jewellery options online (Rahman, 2015). The interviewers also asked the respondents-'What motivates them to visit ecommerce sites or Facebook shopping pages'. About $50 \%$ of the respondents are influenced by the face to face conversations that they have with their friends (WoM), about 20\% is influenced by comments made on Facebook by their friends (eWoM (Note 4)), $10.5 \%$ is motivated by random comments on the public or closed Facebook groups (Feedback) and $10.2 \%$ clicks on the online ad with discounts offers (paid advertisement). Brand endorsement by celebrities (opinion leader) is another paid online marketing technique. About $30 \%$ of the respondents sometimes value the post that a celebrity shares and visit that link, most do not (55\%). This percentage is as same as the online advertisement clicking habit found in table 7 .

Table 11. Online purchasing status

\begin{tabular}{lcccc}
\hline \multirow{2}{*}{ Doing online shopping } & \multicolumn{2}{c}{ Age group 18-25 } & \multicolumn{2}{c}{ Age group 26-35 } \\
\cline { 2 - 5 } & Male $(\%)$ & Female $(\%)$ & Male (\%) & Female (\%) \\
\hline Total $N=302$ & $N=88$ & $N=75$ & $N=87$ & $N=52$ \\
\hline Online shoppers & 31.4 & 42.5 & 26.3 & 22.8 \\
\hline
\end{tabular}

\subsection{Implication of Web Usability and Service Quality}

E-commerce is growing in Bangladesh and internet penetration is increasing. A general scanning of the websites of organizations operating currently in Bangladesh found the need for continuous improvement. Some organizations published their website years ago but have not updated the technical structure to be compatible with today's browser. In most cases the information is outdated. Few questions were asked during the survey to help organizations and developers to improve usability of websites. The first question was to know their preferred search engine. The unarguable winner in this case is Google with $99 \%$ market share. Only one user uses Bing, 3 uses Yahoo and these users are from age group 25-35. 12\% searchers never go beyond the first search result page of Google and 23\% rarely do so. Only 7\% searchers look through page 2 and 3 while choosing which link to click. This habit emphasizes the need for better SEO (Note 5) to ensure websites are coming up on the first page of the search results and the brand is not missing out on organic traffic i.e. unpaid advertisement.

In terms of web browsers, $75 \%$ uses Google Chrome, 56\% uses Firefox and only 6.2\% sometimes uses Internet 
Explorer. The interesting finding is the number of people with smartphones. $93.1 \%$ is using smartphones out of 305 respondents and most of the non-smartphone users (14 people) are 18-25 years old male. Another question was-'Have you recently stopped visiting a website that you used to visit'. $27 \%$ respondent answered 'Yes' to that question. Few of those websites with more than one occurrence in the survey are: Twitter.com, Yohoo.com, Bikroy.com, Banglanews24.com, BDnews24.com and Facebook.com (2 people). Conversation with the respondents found that some of them opened Twitter account to learn about it then left the media after evaluating it as it did not seem 'cool' to them and also because of less popularity among friends. Few respondents abandoned online news portals because of the amount of ads that they did not like, and because of alternate source of the same content. There was an open ended question to allow respondents to suggest what they want when they visit a website. Most Gen Y is looking for correct and updated information. Some suggested ensuring less complexity while navigating the website. Few respondents want to make sure the website is secure and their personal data is safe if they provide. Surprisingly no one in this survey requested for website in Bengali language which is the native language of Bangladesh.

\section{Academic Contribution}

This research contributes to the research area of online consumer behaviour in relation to Generation $\mathrm{Y}$ and growing e-commerce market in Bangladesh. It the first of its kind in the midst of the market transition in Bangladesh and this study will provide a benchmark to the future research works. The findings in this study feed data to the growing community of social media and online consumer engagement researches. Most of such recent researches are developed e-commerce market oriented and this data from a rapidly developing market will add an interesting dimension. Aljukhadar and Senecal (2011) explained three segments of online market: the communicators, the shoppers and the social thrivers. This study complements that and similar online market segmentation analysis by identifying social thrivers and communicators segment in the online landscape of Bangladesh. Continuation of this research in this growing online market may identify all segments of online consumer in near future. Thus this study paves the way for a longitudinal study of digital marketing in Bangladesh similar to the work of Taken Smith (2012), Sultan and Rohm (2004) in US.

\section{Managerial Implications and Applications}

The key purpose of this market research is to assist managers with digital marketing decision making. PWC (2015a) projects that internet will be the largest advertising segment globally by 2019 but the understanding of how consumers consume media will remain as the biggest managerial challenge. Performance marketing leader Criteo (2015) also predicted that mobile devices will have commanding contribution towards global e-Commerce growth, $40 \%$ to be exact by their calculation. Thus cross-device marketing i.e. customizing advertisement for desktops, mobiles, laptops and tablets will be mandatory. Tiago and Veríssimo (2014) recently highlighted the pressure that marketing managers are under to make their online presence effective. Although Bangladesh is not included in the study and projection of these global trending data, the market is showing great potential to become one part of it in coming years. This study provides valuable data to the marketers and the top management to help them make informed digital marketing decision.

The data shows that Gen Y is not active on the internet throughout the day and they are mostly online when brick and mortar shops are usually closed. The management should try to provide customer support services during those traditional off-peak hours while implementing their online growth plan. Also management needs to ensure their website and any other digital presence is mobile compatible. Adequate resources need to be invested to thoroughly test website for usability issues and to ensure the site is updated with information and latest features. Gen Y care about the WoM and eWoM that they receive. Thus organizations not only have to invest in direct paid marketing, they also have to invest in market monitoring such as social media scanning. Bad news travels fast and a negative comment about the brand can become viral in social media in a matter of minutes. Organizations have to prepare themselves for this new kind of media war.

Pull marketing strategy will work better while selling goods and services to Gen Y because they want to engage with the brands and co-create. While thinking of engagement strategy, social cause can serve as a common ground. Thus increasing brand value through Corporate Social Responsibility (CSR) can help digital marketing effort. Offline and traditional advertisement media still attracts Gen Y. Although digital media offers competitively cheaper advertisement options, management cannot take it as a cost saving measure. In a transforming market, they must use the digital media as a complement to the existing advertisement mechanism which are currently bringing revenue to the organization. Gen Y internet using data found in the research will help digital marketers to optimize their advertisement to be more effective and efficient. 


\section{Limitations and Further Research}

Similar to the study that this paper is following (Rahman, 2015), the outcomes in this research are not without limitations and need to be discussed. First, the demography of the survey population do not represent majority of Gen Y in Bangladesh. Most of the participants are either studying at one of the most prestigious private universities in Bangladesh or related to the student. Typically these groups are medium to high achievers in their academic life with access to adequate financial capability to facilitate the use of technology (smartphone, laptop, high speed internet). Conducting the survey on Gen Y with different background may alter some of the findings. Second is the geographic location of the participants. Most of them live and work in the capital city of Bangladesh, Dhaka, where the most viable and feasible access to technology and internet is available. Furthermore, the next advanced city of Bangladesh, Chittagong has not been included in the survey. Third, the unavailability of reference data is another factor. This research is the first of its kind in a rapidly growing online market and researchers with local market knowledge may start to extend this study to assist marketers. Private organizations with interest should invest in such research. The findings will be critical to improve digital advertisement optimization.

The impact of social media needs to be monitored and organizations need to harness its advertising power. Businesses are already using Brand Facebook Pages (BFP) to promote their business. Growth of public Facebook Groups such as DSD (Desperately Seeking in Dhaka) are also evident. In many cases it is becoming a customer service platform for Gen Y. Application of social media in education sector needs to be researched. Online market is rapidly growing in Bangladesh and longitudinal study is recommended.

\section{References}

AdWeek. (2015, 12 January). Infographic: Who's really using Facebook, Twitter, Pinterest, Tumblr and Instagram in 2015. Retrieved June 15, 2015, from http://www.adweek.com/news/advertising-branding/new-social-stratosphere-who-using-facebook-twitter-pi nterest-tumblr-and-instagram-2015-and-beyond-1622

Alexa. (2015). Top sites in Bangladesh. Retrieved May 3, 2015, from http://www.alexa.com/topsites/countries/BD

Aljukhadar, M., \& Senecal, S. (2011). Segmenting the online consumer market. Marketing Intelligence \& Planning, 29(4), 421-435. http://dx.doi.org/10.1108/02634501111138572

AmericanPressInstitute. (2015, 16 March). How Millennials get news: Inside the habits of America's first digital generation. $\quad$ Retrieved July 14, 2015, from http://www.americanpressinstitute.org/publications/reports/survey-research/millennials-news/

Bakewell, C., \& Mitchell, V. W. (2003). Generation Y female consumer decision-making styles. International Journal of Retail \& Distribution Management, 31(2), 95-106. http://dx.doi.org/10.1108/09590550310461994

Black, A. (2010). Gen Y: Who they are and how they learn. Educational Horizons, 92-101. http://www.jstor.org/stable/42923795

Chan-Olmsted, S., Rim, H., \& Zerba, A. (2013). Mobile news adoption among young adults examining the roles of perceptions, news consumption, and media usage. Journalism \& Mass Communication Quarterly, 90(1), 126-147. http://dx.doi.org/10.1177/1077699012468742

Chu, S. C., \& Choi, S. M. (2011). Electronic word-of-mouth in social networking sites: A cross-cultural study of the United States and China. Journal of Global Marketing, 24(3), 263-281. http://dx.doi.org/10.1080/08911762.2011.592461

Conner, C. (2012, July 12). Employees really do waste time at work. Retrieved July 15, 2015, from http://www.forbes.com/sites/cherylsnappconner/2012/07/17/employees-really-do-waste-time-at-work/

Cox, S. (2010). Online social network member attitude toward online advertising formats. Rochester Institute of Technology, US. Retrieved from http://scholarworks.rit.edu/theses/4592

Criteo. (2015). Criteo ecommerce industry outlook 2015. Retrieved May 17, 2015, from http://www.criteo.com/resources/criteo-ecommerce-industry-outlook-2015/

De Vries, N. J., \& Carlson, J. (2014). Examining the drivers and brand performance implications of customer engagement with brands in the social media environment. Journal of Brand Management, 21(6), 495-515. http://dx.doi.org/10.1057/bm.2014.18 
Dent, A. (April 14, 2014). What do Google's earnings reports tell us about adwords trends? Retrieved June 14, 2015 , from http://searchenginewatch.com/sew/opinion/2340777/what-do-googles-earnings-reports-tell-us-about-adwor ds-trends

eMarketer. (2014, September 18). Facebook's US ad revenues outpace users' average daily time spent on the site. Retrieved June 15, 2015, from http://www.emarketer.com/Article/Facebooks-US-Ad-Revenues-Outpace-Users-Average-Daily-Time-Spen t-on-Site/1011215

eMarketer. (2015). Worldwide ad spending. Retrieved July 14, 2015, from http://www.emarketer.com/adspendtool

Google. (2014). Our history in depth. Retrieved 14 June, 2015, from http://www.google.com/about/company/history/

Grameenphone. (2015a). Grameenphone \#theirkhushi. Retrieved July 14, 2015, from https://www.youtube.com/watch?v=MFNqNG6Apj4

Grameenphone. (2015b). \#theirkhushi. Retrieved July 14, 2015, from http://www.grameenphone.com/personal/offers/theirkhushi

Internet World Stats. (2015, 14 June). Asia marketing research, internet usage, population statistics and Facebook information. Retrieved July 14, 2015, from http://www.internetworldstats.com/asia.htm\#bd

Lewis, S. C. (2008). Where young adults intend to get news in five years. Newspaper Research Journal, 29(4), 36.

Lichy, J. (2012). Towards an international culture: Gen Y students and SNS? Active Learning in Higher Education, 13(2), 101-116. http://dx.doi.org/10.1177/1469787412441289

Mangold, W. G., \& Faulds, D. J. (2009). Social media: The new hybrid element of the promotion mix. Business Horizons, 52(4), 357-365. http://dx.doi.org/10.1016/j.bushor.2009.03.002

Meade, A. (2014, 8 July). Five things about Gen Y that charities need to know. Retrieved July 15, 2015, from http://www.theguardian.com/voluntary-sector-network/2014/jul/08/five-things-charities-need-to-know-abou t-generation-y

Nettelhorst, S. C., Jeter, W. K., \& Brannon, L. A. (2014). Be careful what you wish for: The impact of advertisement choice on viewers' expectations. Computers in Human Behavior, 41, 313-318. http://dx.doi.org/10.1016/j.chb.2014.10.009

Noble, S. M., Haytko, D. L., \& Phillips, J. (2009). What drives college-age Generation Y consumers? Journal of Business Research, 62(6), 617-628. http://dx.doi.org/10.1016/j.jbusres.2008.01.020

Prensky, M. (2001). Digital natives, digital immigrants part 1. On the Horizon, 9(5), 1-6.

PWC. (2015a). Internet advertising-Key insights at a glance. Retrieved July 15, 2015, from http://www.pwc.com/gx/en/global-entertainment-media-outlook/segment-insights/internet-advertising.jhtml

PWC. (2015b). Retail categories: How consumers shop. Total Retail. Retrieved April 23, 2015, from http://www.pwc.com/gx/en/retail-consumer/retail-consumer-publications/global-multi-channel-consumer-s urvey/retail-subsectors.jhtml

Rahman, S. M. (2015). Consumer expectation from online retailers in developing e-commerce market: An investigation of generation $\mathrm{Y}$ in Bangladesh. International Business Research, 8(7), 121. http://dx.doi.org/10.5539/ibr.v8n7p121

Sharma, A. (2011). Take-off of online marketing: Casting the next generation strategies. Business Strategy Series, 12(4), 202-208. http://dx.doi.org/10.1108/17515631111155160

Stelzner, M. A. (2015, May). 2015 Social media marketing industry report. Social Media Examiner. Retrieved June 10, 2015, from http://www.socialmediaexaminer.com/SocialMediaMarketingIndustryReport2015.pdf

Sultan, F., \& Rohm, A. J. (2004). The evolving role of the internet in marketing strategy: An exploratory study. Journal of interactive Marketing, 18(2), 6-19. http://dx.doi.org/10.1002/dir.20003

Taher, F. (January 1, 2015). 2015 digital marketing trend report for Bangladesh. Retrieved May 14, 2015, from http://sdasia.co/2015/01/01/2015-digital-marketing-trend-report-bangladesh/ 
Taken, S. K. (2012). Longitudinal study of digital marketing strategies targeting Millennials. Journal of Consumer Marketing, 29(2), 86-92. http://dx.doi.org/10.1108/07363761211206339

Tiago, M. T. P. M. B., \& Veríssimo, J. M. C. (2014). Digital marketing and social media: Why bother? Business Horizons, 57(6), 703-708. http://dx.doi.org/10.1016/j.bushor.2014.07.002

Zaremohzzabieh, Z., Samah, B. A., Omar, S. Z., Bolong, J., \& Kamarudin, N. A. (2014). Addictive Facebook use among university students. Asian Social Science, 10(6), 107. http://dx.doi.org/10.5539/ass.v10n6p107

\section{Notes}

Note 1. Longitudinal study is observation of a subject over a long period of time.

Note 2. ROI: Return of Investment.

Note 3. WoM: Word of Mouth.

Note 4. eWoM: Electronic Word of Mouth.

Note 5. SEO: Search Engine Optimization.

\section{Copyrights}

Copyright for this article is retained by the author(s), with first publication rights granted to the journal.

This is an open-access article distributed under the terms and conditions of the Creative Commons Attribution license (http://creativecommons.org/licenses/by/3.0/). 